\title{
INVENTORY CONTROL OF DISPOSABLE MEDICAL MATERIALS AT THE BALI MANDARA EYE HOSPITAL
}

\author{
Menilik Pengendalian Persediaan Bahan Habis Pakai Farmasi di \\ Rumah Sakit Mata Bali Mandara
}

\author{
*Ni Wayan Yuli Yudianti ${ }^{1}$, Putu Nina Eka Lestari"1, Gde Sri Darma1, IB Raka Suardana1 \\ ${ }^{1}$ Undiknas Graduate School, Denpasar, Indonesia \\ Correspondence*: \\ Address: Universitas Pendidikan Nasional, Jl. Bedugul No.39, Sidakarya, Denpasar, Indonesia | e-mail: wayan.yuli09@gmail.com
}

\begin{abstract}
Background: As a health service institution, hospitals have characteristics and management complexities which have an impact on their financing aspects. Controlling the supply of pharmaceutical supplies aims to create a balance between supply and demand in order to realize effective and efficient health services.

Aims: This study aimed to design a method for controlling the optimal supply of disposable medical materials at the Bali Mandara Eye Hospital, Bali.

Methods: This is a qualitative study based on in-depth interviews with three informants, and involving 11 doctors (users) to determine the critical value of disposable medical materials.

Results: $A B C$ analysis was used to classify all types of goods based on their importance to determine priorities based on the value of use. The budget allocation was dominated by only a small portion or only a few types of pharmaceutical supplies. The results show that there was a decrease in the total cost of inventory by $19.14 \%$ after the application of the EOQ method. The application of the reorder point (ROP) method can anticipate the occurrence of stock outs or vacancies.

Conclusion: The EOQ method is more efficient than the conventional method applied at the Bali Mandara Eye Hospital Pharmacy Installation. The EOQ and ROP methods greatly affect the efficiency and effectiveness of controlling the inventory of medical disposable materials at the Bali Mandara Eye Hospital.
\end{abstract}

Keywords: : inventory control, effective and efficient, medical disposable materials,

\begin{abstract}
Abstrak
Latar Belakang: Sebagai institusi pelayanan kesehatan, rumah sakit memiliki karakteristik dan kompleksitas manajemen yang berdampak pada aspek pembiayaannya. Pengendalian persediaan perbekalan farmasi bertujuan menciptakan keseimbangan antara persediaan dan permintaan agar terwujud pelayanan kesehatan yang efektif dan efisien.

Tujuan: Penelitian ini bertujuan untuk membuat rancangan metode pengendalian persediaan bahan habis pakai farmasi yang optimal di Rumah Sakit Mata Bali Mandara Provinsi Bali.

Metode: Analisis $A B C$ digunakan untuk mengelompokkan semua jenis barang berdasarkan kepentingannya sehingga dapat ditentukan prioritas pesanan berdasarkan nilai guna. Padahal, alokasi anggaran didominasi hanya sebagian kecil atau hanya beberapa jenis perbekalan farmasi. Penelitian ini merupakan penelitian kualitatif dengan wawancara mendalam dengan tiga orang informan, dan dengan melibatkan 11 dokter (user) untuk menentukan nilai kritis bahan habis pakai farmasi.

Hasil: Terjadi penurunan total biaya persediaan sebesar 19,14\% setelah penerapan metode EOQ. Penerapan metode Reorder Point (ROP) dapat mengantisipasi terjadinya stock out atau kekosongan.

Kesimpulan: Metode EOQ lebih efisien dibandingkan dengan metode konvensional yang diterapkan di Instalasi Farmasi RS Mata Bali Mandara. Metode EOQ dan ROP sangat berpengaruh pada efisiensi dan efektivitas pengendalian persediaan bahan habis pakai farmasi di IFRS Mata Bali Mandara.
\end{abstract}

Kata kunci: bahan habis pakai farmasi, efektif dan efisien. pengendalian persediaan, 


\section{Introduction}

Throughout the COVID-19 pandemic across the world, for more than three months the public stayed at home. Working, studying, and most other daily activities are being done from home. Many changes have occurred, not only in the fields of education and economics, but also in the environmental field, especially in regards to the problem of solid waste. According to the Indonesian Ministry of Health and the Healthy Living Community Movement has guidelines for managing hospital waste in referral hospitals, emergency hospitals, and community health centers. They state that materials categorized as COVID-19 waste include goods or materials that will not be reused and are left over from activities wherein they were potentially contaminated by infectious substances, patients, and/or officers in health care facilities that handle COVID-19 patients. These include used masks, used gloves, used bandages, used tissue, used food and beverage plastic, used food and beverage paper, used syringes, used infusion sets, used personal protective equipment, and patient food scraps from service activities in the ER, isolation room, ICU room, treatment room, and other service rooms. It can be seen that COVID-19 waste is included in the category of solid medical hazardous and toxic waste (B3) (Gurumurthy et al., 2020). As health service institutions, hospitals have characteristics and management complexities which have an impact on their financing aspects (Ballou, 2004). The procurement of pharmaceutical supplies in the form of drugs and consumables represents a large portion of the costs in the health industry, particularly hospitals. The provision of quality pharmaceutical supplies is very important in supporting health services in hospitals, and this activity cannot be separated from the hospital supply management. Proper pharmaceutical supply management is essential to ensure the availability of adequate drugs and consumables for health services to patients and as a source of income for hospitals (Dewi et al., 2020).
Transportation and inventory costs are interrelated and comprise the greatest portion of total logistics costs (Ballou, 2004). Controlling the supply of pharmaceutical supplies is one part of logistics management. It aims to manage the availability of pharmaceutical supplies according to needs in order to ensure that there is no shortage or excess supply. Shortages cause disruption of service activities to patients. On the other hand, excessive inventory causes cost overruns and restrained capital, which, if the turnover is not achieved, will cause losses for the hospital. Stock of consumable medical materials is considered to be good when the availability of consumable medical materials is at an optimal amount, not less than the safety stock, and not more than three times the monthly use. Stagnant conditions lead to negative impacts such as increased expiration of medical consumables, lost opportunities, and lost revenue for clinical pharmacies. Conditions of deprivation not only causes a decrease in income but also contributes to higher mortality and morbidity for patients in critical condition. Lost opportunities and lost revenue occur in a stagnant state because inventory costs, ordering costs, and handling costs are increasing (Essam et al., 2020; Hales et al., 2017; Minken and Johansen, 2019).

According to Satibi (2014), a good supply of pharmaceutical supplies is when the availability is at an optimal amount, not less than the safety stock and no more than three times of monthly usage. Controlling the supply of pharmaceutical supplies aims to create a balance between supply and demand in order to realize effective and efficient health services. Good inventory management will be able to increase hospital revenue while still ensuring quality health services for patients (Rochmah, 2019). The results of Octaviany's (2018) study state that economic order quantity $(E O Q)$ is highly recommended in controlling drug supplies in hospitals. Hartih et al. (2013) stated that the EOQ and ROP methods can reduce the value of regular drug supplies in hospitals. The same thing is also shown in a study by Dewi et al. (2020), which states that EOQ is an 
effective and efficient method of inventory control to prevent drug vacancies and stagnation. An inventory control system is needed to maintain the availability of optimum pharmaceutical logistics in order to meet the needs in the right quantity, quality, and time, as well as minimize cost. Inventory control activities can achieve budget efficiency and minimize risks arising from excess or under-stock (Akhmad, 2018). Management of drugs and medical consumables that are effective and efficient is an important factor in hospital management. This ensures optimal availability of drugs and medical consumables in terms of quality, type, amount, time, and rational use. This allows for the available funds to be used as effectively as possible for health services (World Health Organization, 2014). The expenditure budget for drugs and medical consumables at the hospital is the largest component of hospital expenditure. In many developing countries, spending on medicines and medical consumables in hospitals accounts for about $40 \%$ to $50 \%$ of the total hospital budget. This large budget must be managed effectively and efficiently in order to meet the needs of healthcare for patients. Efficient use of medical consumables can be realized through a good inventory planning and control system. Inefficient management of drugs and consumable medical materials will have a negative impact on hospital costs and patient recovery rates (Indonesian Ministry of Health, 2019).

The Bali Mandara Eye Hospital (BMEH) is a special type A hospital owned by Bali's provincial government which provides eye health services. Similar to service companies in general, the BMEH also needs supplies to support its operational activities. This study focuses on the supply of disposable medical materials because they take up more of the budget than any other supply, and they are a vital element for the implementation of health service activities at the BMEH. All pharmaceutical supplies at the BMEH are managed one door under the Hospital Pharmacy Installation (IFRS). The IFRS is a unit in the hospital that is fully responsible for managing the logistics at the hospital. Based on a preliminary study conducted at the BMEH Pharmacy Installation, planning for the need for pharmaceutical supplies is carried out using the consumption method based on historical usage in the last three months. Additional orders are made with an estimate of $20 \%-25 \%$ of the average usage. The calculation of needs is still done manually, even though there is a hospital information system to manage supplies. Currently the hospital information system is only used to record incoming and outgoing supplies, but cannot provide information about the optimal quantity to be ordered or when these items should be ordered.

Planning is carried out using the consumption method based on the average usage of the last three months adjusted to the remaining stock in the warehouse. The procurement of drugs and consumable medical materials is carried out directly by the provider (distributor) by taking into account the ease of orders, the availability of goods from the distributor, and the capacity of the drug warehouse. In addition, at the BMEH Pharmacy Installation, there has never been a method of controlling drug supplies/consumables through inventory classification to facilitate supervision. This needs to be done because the number of supplies of drugs/consumables in the IFRS BMEH Drug Store is very large, namely 672 items. Thus, it is necessary to group according to the level of importance to determine the types of drugs/consumables that need to be prioritized. Based on this phenomenon, the researcher wanted to help develop a control system for the supply of pharmaceutical supplies at the BMEH to fulfill the role of the Pharmacy Installation as one of the hospital's revenue centers. Planning with the consumption method becomes inaccurate when there is an increase in cases. There are still frequent purchases of cito outside of planning, meaning the service is less effective and efficient. This shows the need for good management of pharmaceutical supplies, especially disposable medical materials. It is necessary to implement proper planning; therefore, an adequate analysis is required, such as $A B C, E O Q$, or ROP. Sensitivity analyses are conducted based on the parameters including truck loading capacity, inventory carrying cost 
percentages, unit shortage costs, unit ordering costs, and unit transport costs to support optimal distribution system design (Lai et al., 2021). This is consistent with research by Chang et al. (2008); Fan et al. (2009); Hales et al. (2017); Tongzon et al. (2009); Ugboma et al. (2006), who examined other objects, namely port selection, influenced by several factors in accordance with Buffa's (1986) theory of restocking inventory in groups, which supports this study. Researchers wanted to get an overview of the process of controlling pharmaceutical supplies at the BMEH, before and after the application of the EOQ and ROP methods, to produce a solution for controlling hospital supplies, especially pharmaceutical supplies.

\section{Method}

This study used a quantitative research design. A qualitative approach was used to describe the process of controlling consumable supplies at IFRS $\mathrm{BMEH}$. Data collection was carried out via in-depth interviews with four informants, as well as through observation. Meanwhile, operational research was done by involving users or doctors to determine the critical value of disposable medical materials by filling out a Google Form questionnaire. In addition, secondary data processing was also carried out by obtaining a list of consumable pharmaceutical supplies for the period of January 2019-December 2019 , which was analyzed using the $A B C$ method. This research was also conducted by comparing the total inventory cost before and after the application of the EOQ and ROP methods to see whether the application of these methods can increase the efficiency and effectiveness of the inventory of disposable medical materials at the BMEH Pharmacy Installation.

\section{Result and Discussion}

\section{Inventory control at the BMEH}

Based on the results of in-depth interviews with the four informants, it is known that the planning process for the supply of disposable medical materials at the BMEH Pharmacy Installation is done with the consumption method. This method calculates the need for disposable medical materials based on the average usage for the last three months adjusted to the budget available, as well as based on the remaining stock at the hospital. The selection and planning process for disposable medical materials at the Pharmacy Installation is guided by the BMEH Formulary and the National Formulary. The method used for the inventory planning system and the procurement of consumables is the consumption method and hospital needs. According to the informant, the consumption method has several obstacles, one of which is when there is an increase in cases, the demand from the unit also increases, and as a result the drug warehouse cannot meet the demand. The first informant stated that the use of the consumption method was not very accurate. Ideally, planning for drugs/consumables is done using several methods such as ABC, VEN, and adjusting to conditions in the field to further validate planning data. Planning is ideally done using a method that can be accounted for and the basics of planning that have been determined, including consumption, epidemiology, and a combination of consumption and epidemiology. Planning must also include consideration of available budget, priority setting, remaining inventory, previous period usage data, order waiting time, and development plans. Eissa et al. (2020) evaluated suppliers in a healthcare facility by applying statistical process optimization tools in managing the inventory of products' quality. They selected random records of container deliveries from three different suppliers and analyzed products' characteristics using statistical process control (SPC) tools. The results indicated that most dominant manufacturers supplied the product having specifications close to the target values, whereas the least contacted vendor revealed the highest precision.

The availability of medical disposable materials at the BMEH was monitored 
through stock cards and the Hospital Information System (SIMRS). However, the data on the use of medical disposable materials from SIMRS are historically inaccurate, forcing manual usage calculations to still be carried out based on the amount of expenditure on the card and stock of goods. The combination of the FIFO (first in first out) and FEFO (first expired first out) methods is used at the time of releasing goods to prevent damaged and expired goods. This evaluation is carried out every quarter, namely in March, June, September, and December. In addition, an evaluation of the expired date of medical disposable materials is also carried out at the time of stock-taking to find out which items will expire in the next year. Physical checks are also done every day to ensure that the items recorded on the stock card match their physical quantities. Overall, the obstacles faced in controlling the supply of medical disposable materials at the BMEH Pharmacy Installation, according to the informant, were when there is an increase in cases and inadequate procurement planning using the consumption method, which led to an increase in the demand for consumables. As a result, there are frequent cito (immediate) orders from distributors, and inventory control becomes ineffective and inefficient. The purchase of cito or small purchases is not in line with the purpose of inventory control as expressed by Satibi (2014). In addition, the calculation of needs based on hospital policy is still not optimal where there are still excess orders for certain items. This means that there is excess stock which, if not properly supervised, will accumulate and expire. Products that have piled up in the warehouse will become retained capital for the hospital and will increase storage costs. In addition, vacancies in distributors or factories and late delivery also often make it difficult to procure medical disposable materials supply.

\section{ABC Usage Analysis}

Based on Table 1, from 174 items of analyzed medical disposable materials using the $A B C$ analysis, it is known that the Group $A$ is the consumable material with the highest usage. Group A had a usage of 64,802 or takes up $69.19 \%$ of the total usage, consisting of 12 items or $6.89 \%$ of the total items of disposable medical materials. Group B had consumables with moderate use, namely 19,168 or $20.46 \%$ of the total usage, consisting of 25 items or $14.37 \%$ of the total items of disposable medical materials. Group $\mathrm{C}$ had consumables with low usage, namely 9,693 or $10.35 \%$ of the total usage, consisting of 137 items or $78.74 \%$ of the total items of disposable medical materials.

The results of the calculation of the value of use from the $A B C$ analysis show that the percentage composition of drug items for groups $A, B$, and $C$ was inversely proportional to the percentage of total use. Group A, as opposed to groups B and C, should have tighter physical inventory control, and the accuracy of inventory records on item $A$ should be verified more frequently (Heizer et al., 2017). The calculation results also show that group $\mathrm{C}$ used as much as $10.35 \%$ of the drug supply, but covered $78.74 \%$ of all drug items. This indicates that there were many items in group $\mathrm{C}$ with low movement. The existence of this calculation can be used to select which disposable medical materials really need to be procured and which ones do not need to be re-stocked because too many low-moving items will make monitoring difficult and risk expiration. $A B C$ analysis was used to classify all types of goods based on their importance to determined priorities based on the value of use. In fact, the budget allocation was dominated by only a small portion or only a few types of pharmaceutical supplies. Types of pharmaceutical supply can be budget-heavy because of their many uses. This is in accordance with the Pareto principle stated in the theory of (Heizer et al., 2017). This theory states a small proportion of goods are the same types of items as those in group $A$, which is very 
important because they have the greatest use value. This means they require strict attention in controlling inventory, where it can be monitored within a fixed and strict time period (e.g. every month) using the EOQ order model. The attention given to control group $B$ is not too strict, unlike group A. Evaluation can be done within a period of 6 months or 3 months. Whereas for group $\mathrm{C}$, inventory control in this group was carried out very loosely compared to groups A and B. The evaluation could be carried out in a period of one year or every 6 months.

\section{ABC Analysis of Investment Value}

There were 174 items of disposable medical materials. After being analyzed with the $A B C$ Investment analysis, it is known that Group A consisted of 12 items or $6.90 \%$ of the disposable medical materials with an investment value of Rp.3,110,809,628.00 or a share of $68.28 \%$ of the total investment value. Group B consisted of 22 items or $12.64 \%$ of the total items of disposable medical materials with an investment value of Rp.977,726,591.93 or a share of $21.46 \%$ of the total investment value. Group C consisted of 140 items or $80.46 \%$ of the total disposable medical materials with an investment value of Rp. $467,416,118.71$ or $10.26 \%$ of the total investment value.

This shows that Group A absorbed very high investment; therefore, it is necessary to regulate the inventory. This is especially important to avoid stockpiling because disposable medical materials with high investment value also cause high storage costs. To reduce storage costs, periodic small orders can be made. However, it should also be noted that there is no stock out because the cost of purchases outside of planning is also high due to the high value of drugs. Through the $A B C$ analysis of investment value, it was found that Group C had many types of consumables that were barely used between January 2019-December 2019. Thus, it is necessary to evaluate the types of consumables that currently exist, whether they need to be procured or can be arranged for procurement according to orders. This is to eliminate the need for inventory that is at risk of damage, expiration, and increased storage costs. To reduce storage costs, periodic small orders can be made. However, it should also be noted that there is no stock out because the cost of purchasing outside of planning is also high due to the high value of goods.

\section{ABC Critical Index Analysis}

Group A of the ABC critical index analysis consisted of 11 items, or as much as $6.32 \%$ of the total disposable medical materials. Group B consisted of 105 items, or as much as $60.34 \%$ of the disposable medical materials.

Group C consisted of 58 items, or as much as $33.33 \%$ of the total disposable medical materials. Inventory classifying is a must when it comes to large quantities of products. Consumable medical supplies were classified using the $A B C$ analysis of critical index to see the level of criticality based on the clinical importance of each item. There were 11 medical consumables included in Group A. These items included medical consumables which need attention in procurement. This is because, in addition to having high use value and investment value, they also have a high level of criticality due to their use which cannot be postponed to avoid vacancies. In addition, fund management can be allocated to ensure the availability of critical index Group A consumables to meet demand. In other words, monitoring of Group A critical index needs to be done strictly to provide optimal service for patients. The $A B C$ analysis of the critical index shows that the critical value was two times the value in use and the value of investment. In other words, the priority of procurement was not based on the value of the investment or the value of use, but rather on how important the goods were based on their use. For example, Rohtovisc and ophthalmic drape cannot be suspended even though they 
Table 1. List of Group A medical disposable materials based on the $A B C$ critical index analysis

\begin{tabular}{llc}
\hline No. & \multicolumn{1}{c}{ Name of medical disposable materials } & Critical Index of ABC Value \\
\hline 1 & Rohtovisc & 11.17 \\
2 & Opthalmic Drape Green OM & 10.67 \\
3 & AOK Microknife 15,0 deg str & 10.33 \\
4 & Probe Icare TA 03 & 10.00 \\
5 & Cons comb vit pro pak 23 GA & 10.00 \\
6 & Centurion ACT IRR FMS Pack 0.9 Ultra Bal & 10.00 \\
7 & Cassete Phaco infiniti (Ultrasound FMS Basic) & 10.00 \\
8 & Arciolane 5500 & 9.67 \\
9 & Arciolane 1300 & 9.67 \\
10 & OPO 71-Next Generation Pheco DP-Pack & 9.64 \\
11 & Grieshaber Rev ILM & 9.64 \\
\hline
\end{tabular}

have small investment values because Rohtovisc is a viscoelastic fluid which functions to protect intraocular tissue during cataract surgery. Meanwhile, the ophthalmic drape functions to absorb fluid during eye surgery.

The $A B C$ critical index analysis showed that the critical value was twice the value in use and the value of investment. In other words, the priority of procurement is not based on the value of the investment or the value of use, but rather on how important the goods are based on their use. Based on the research results, there were 11 disposable medical materials included in the critical index group A. These eleven items include items that need attention in procurement because they have high use value and investment value, but also have a high level of criticality because their use cannot be postponed so that no vacancies may occur. In other words, the priority of procurement is not based on the value of the investment or the value in use, but rather on how important the consumables have important value. In addition, fund management can be allocated to ensure the availability of critical index group $A$ medical disposable materials to meet demand. Monitoring of group A critical index needs to be done strictly so that patients can get optimal care. By selecting the appropriate inventory method, the total cost of supplies can be reduced while maintaining the level of service for patients. With the selected inventory method, it will be known when to place an order (reorder point) and the recommended amount of purchases (EOQ).

\section{EOQ of Group A Medical Disposable} Materials, ABC Analysis of Critical Index When calculating the EOQ for each order, data were required regarding the number of requests per year, ordering costs, and carrying costs. The number of requests per year was determined based on the results of document review. Ordering fees and storage costs were obtained through in-depth interviews with the pharmacist coordinator of procurement at the pharmacy warehouse. According to informants in the interview, ordering goods has never taken these costs specifically. In this study, researchers used the theory from (Heizer et al., 2017) where for storage costs the percentage of costs in general is $26 \%$ of the unit cost or price per item of goods. Gurumurthy et al. (2020) stated that a deep dive into the A-class items revealed that some of the medical supplies fell under both vital and scarce categories. Hence, it was recommended that the case hospital should follow the economic order quantity (EOQ) with the safety stock approach, as these items were to be shipped from other states in India. Subsequently, the focus should be on developing a local supplier and attempts should be made to establish a kanban system with adequate information sharing.

When placing an order with a distributor, the procurement coordinator pharmacist uses the WhatsApp (WA) 
service. The data package used every time you order with the WhatsApp call service for 1 minute is $0.2 \mathrm{MB}$, at a cost of Rp. $1 / \mathrm{KB}$ (m.industry.co.id). If the WA call duration for each order is 5 minutes, then the data package used is $1 \mathrm{MB}$, equivalent to 1,000 $\mathrm{KB}$. If calculated in rupiah, it becomes Rp.1,000 per order.

$E O Q$ calculation data showed that items with high prices (example: Cons comb vit pro pack $23 \mathrm{GA}$ ), although high in usage, were low in EOQ because storage costs were quite high ( $26 \%$ of the unit cost). Storage costs will be high if the medical supply provider stores large amounts of it and also risks increasing costs due to expiration, damage, and loss. Meanwhile, EOQ items with cheaper prices, such as Rohtovisc, were relatively higher in EOQ because their storage costs were not too high and it was not too risky storing a considerable amount of them. Overall, the application of the EOQ method had an impact on reducing the total cost of inventories by $19.14 \%$. This is in line with research which states that the EOQ method can help companies minimize inventory costs (Dewi et al., 2020). Planning with the EOQ method in a company will be able to minimize the occurrence of stock out, prevent interference with the processes within the company, and allow the company to save on inventory costs. This is also in line with Ercis and Widodo (2013) research, which states that the EOQ and ROP analyses are some of the strategies that can be adopted in an effort to control costs and increase efficiency both in terms of quantity and time of ordering. Hospital operational costs will be more efficient with cost efficiency in inventory management. Both ordering and storage costs must be balanced to avoid losses. If one of them swells, there will be a problem and this will hinder service to patients. If the number of orders during a certain period increases, the annual order fee will also increase. Conversely, if the number of orders is reduced, the ordering costs will also be reduced. Meanwhile, the storage fee depends on the size of the order. The bigger the order size, the higher the storage cost and vice versa. EOQ is the point where there is a balance between ordering costs and storage costs. Minken and Johansen (2019) propose an EOQ model incorporating detailed transport costs. This considers not only the transportation costs but also loading and unloading costs. They argue that a policy measure that reduces expected transport time and its uncertainty would enhance firms to reduce their safety stocks while maintaining the same service levels (or improve service levels with the same level of safety stock).

Table 2. Comparison of total inventory cost with EOQ method and conventional hospital method

\begin{tabular}{lccrr}
\hline \multicolumn{1}{c}{$\begin{array}{c}\text { Name of medical } \\
\text { disposable materials }\end{array}$} & $\begin{array}{c}\text { Average } \\
\text { Procurement } \\
\text { Per Month }\end{array}$ & EOQ & $\begin{array}{c}\text { Total Cost } \\
\text { Before EOQ } \\
\text { Implementation } \\
(\text { Rp) }\end{array}$ & $\begin{array}{c}\text { Total Cost After } \\
\text { EOQ } \\
\text { Implementation } \\
\text { (Rp) }\end{array}$ \\
\hline Rohtovisc & 227 & 24 & $2,715,577$ & 744,910 \\
\hline Opthalmic Drape Hijau OM & 201 & 34 & $1,036,742$ & 366,133 \\
\hline AOK Microknife 15,0 deg str & 202 & 17 & $3,801,548$ & $1,029,263$ \\
\hline Cassete Phaco infiniti (Ultrasound FMS Basic) & 17 & 2 & $1,744,513$ & $1,486,116$ \\
\hline Centurion ACT IRR FMS Pack 0.9 Ultra Bal & 15 & 2 & $2,571,440$ & $2,286,408$ \\
\hline Cons comb vit pro pak 23 GA & 15 & 1 & $12,790,260$ & $11,374,322$ \\
\hline Probe Icare TA 03 & 142 & 41 & 382,839 & 206,145 \\
\hline Arciolane 1300 & 4 & 1 & $1,123,940$ & $1,857,755$ \\
\hline Arciolane 5500 & 7 & 1 & $2,397,367$ & $3,018,829$ \\
\hline Grieshaber Rev ILM & 5 & 1 & $1,657,276$ & $1,810,689$ \\
\hline OPO 71-Next Generation Pheco DP-Pack & 12 & 2 & $1,582,921$ & $1,536,493$ \\
\hline Total & & & $31,804,423$ & $25,717,062$ \\
\hline Efficiency & & & & $6,087,361$ \\
\hline (\%) & & & & $19.14 \%$ \\
\hline
\end{tabular}


Table 3. Results of ROP calculation for medical disposable materials for Group A $\mathrm{ABC}$ analysis of critical index

$\begin{array}{lcccc}\text { Name of medical disposable materials } & \begin{array}{c}1 \text { year } \\ \text { usage }\end{array} & E O Q & \begin{array}{c}\text { average } \\ \text { usage }\end{array} & \begin{array}{c}\mathrm{ROP} \\ (\mathrm{d} \times \mathrm{L})\end{array}\end{array}$

(D) per day $(d)$

\begin{tabular}{lccccc}
\hline Rohtovisc & 2,741 & 24 & 9.26 & 1 & 9 \\
\hline Opthalmic Drape Hijau OM & 2,443 & 34 & 8.25 & 1 & 8 \\
\hline AOK Microknife 15,0 deg str & 2,378 & 17 & 8.03 & 1 & 8 \\
\hline Cassete Phaco infiniti (Ultrasound FMS Basic) & 199 & 2 & 0.67 & 1 & 1 \\
\hline Centurion ACT IRR FMS Pack 0.9 Ultra Bal & 171 & 2 & 0.58 & 1 & 1 \\
\hline Cons comb vit pro pak 23 GA & 168 & 1 & 0.57 & 1 & 1 \\
\hline Probe Icare TA 03 & 1,786 & 41 & 6.03 & 1 & 6 \\
\hline Arciolane 1300 & 49 & 1 & 0.17 & 1 & 0 \\
\hline Arciolane 5500 & 88 & 1 & 0.30 & 1 & 0 \\
\hline Grieshaber Rev ILM & 33 & 1 & 0.11 & 1 & 0 \\
\hline OPO 71-Next Generation Pheco DP-Pack & 143 & 2 & 0.48 & 1 & 0 \\
\hline
\end{tabular}

Overall, the application of the EOQ method has an impact on reducing the total cost of inventories by $19.14 \%$. This is in line with Dewi et al. (2020) research which states that the EOQ method can help companies minimize inventory costs. This is also in line with Ercis' (2013) which states that $E O Q$ and ROP analysis is a strategy in an effort to control costs and increase efficiency both in terms of quantity and time of ordering, so that with cost efficiency in inventory management, hospital operational costs will be more efficient.

\section{ROP (Reorder Point) of Medical Disposable Materials Group A ABC Analysis of Critical Index}

The calculation of the reorder point (ROP) requires an average number of usage per day, lead time, and safety stock. The average number of usage per day can be calculated based on document review. Based on the results of in-depth interviews with the second informant, it is known that the waiting time required from the time of ordering until the goods are received (lead time) is usually one day because almost all distributors are in the city. Meanwhile, information was also obtained that the safety stock policy was not enforced, because it is included in the calculation of the addition every time planning is $20-25 \%$.

From the calculation of ROP without using a safety stock policy, it was found that four items had an ROP value equal to zero. This is also due to the optimal amount in each order (EOQ) being one. In other words, it can be assumed that the hospital will place an order when the inventory level for the item reaches zero, and the company will immediately receive the item. However, this has the risk of hindering service activities, especially if there is a lack of goods or late delivery from the distributor. According to the Heizer et al., (2017), the calculation of safety stock (safety stock) can help reduce orders outside of planning due to stock outs which result in additional costs. With the results of the calculation of safety stock, officers at the logistics warehouse can be helped to determine when to place an order. This can be especially helpful if there is a delay in delivery from distributors who are outside the area and during certain periods in the year such as religious holidays and national holidays. This way, the availability of medical disposable materials is maintained and does not interfere with service to patients.

\section{Conclusion}

The EOQ method is more efficient than the conventional method applied at the BMEH Pharmacy Installation, where there was a decrease in the total cost of supplies by $19.14 \%$ after implementing this method. The application of the ROP method can anticipate the occurrence of stock outs or vacancies. These two methods greatly affect the efficiency and effectiveness of 
controlling the inventory of disposable medical materials at the BMEH. The BMEH Pharmacy Installation does not yet have an adequate pharmaceutical supply control system. Planning and procurement are still carried out conventionally based on the historical usage of the last three months and are carried out by manually checking which items will or have run out. The BMEH Pharmacy Installation has carried out accurate records of the entry and exit of goods and the expiry date of pharmaceutical supplies manually with a stock card, which can become a reference in implementing the $E O Q$ and $R O P$ methods in the future. $A B C$ analysis serves to determine inventory priority. Inventory items with high investment value require a more stringent control system than those with low investment value.

\section{Suggestion}

Ordering costs and storage costs for pharmaceutical supplies should be calculated in real time, in order to produce a more accurate EOQ calculation to increase the efficiency of hospital operational costs. The accurate calculation cannot be based on estimates, especially if there is a delay in delivery from distributors. Development of a hospital information system (SIMRS) is necessary to the inventory process. It plays a part in creating an integrated system that can support logistics management tasks in pharmaceutical installations in the planning and procurement process.

\section{Abbreviations}

BMEH: Bali Mandara Eye Hospital; EOQ: economic order quantity; ROP: Reorder Point, FIFO: first in first out; FEFO first expired first out; SIMRS: hospital information system; SPC: statistical process control; IFRS: Hospital Pharmacy Installation.

\section{Declarations}

\section{Ethics Approval and Consent Participant}

This study has passed the ethics review from the BMEH.

\section{Conflict of Interest}

We declare that we do not conflict with anyone's interest.

\section{Availability of Data and Materials}

The availability of data and materials based on demand from journal and readers

\section{Authors' Contribution}

NWYY and PNEL conceptualised the study design and article. NWYY, GSD, and IBRS prepared the original draft of the manuscript.

\section{Acknowledgment}

First for parents, husband, and children, Then for the supervisor Dr. Ni Putu Nina Eka Lestari, MM.

\section{References}

Akhmad. (2018). Manajemen Operasi Teori dan Aplikasi dalam Dunia Bisnis. Yogyakarta: ANDI Offset.

Ballou, R. H. (2004). Business Logistics/supply Chain Management: Planning, Organizing, and Controlling the Supply Chain. New Jersey: Pearson Prentice Hall.

Buffa, F. P. (1986). Restocking Inventory in Groups: A Transport Inventory Case. International Journal of Physical Distribution \& Materials Management, 16(3), 29-44. https://doi.org/10.1108/eb014632

Chang, Y. T., Lee, S. Y., and Tongzon, J. L. (2008). Port selection factors by shipping lines: Different perspectives between trunk liners and feeder service providers. Maritime Policy and Management, 32(1), 877-885.

https://doi.org/10.1016/j.marpol.2008.01 .003

Dewi, E. K., Dahlui, M., Chalidyanto, D., and Rochmah, T. N. (2020). Achieving costefficient management of drug supply via economic order quantity and minimummaximum stock level. Expert Review of Pharmacoeconomics and Outcomes Research, 20(3), 289-294. https://doi.org/10.1080/14737167.2019. 1633308

Essam Eissa, M., Eissa, M., and Rashed, E. (2020). Application of statistical process optimization tools in inventory management of goods quality: Suppliers 
evaluation in healthcare facility. Journal of Turkish Operations Management, 4(1), 388-408.

Ercis, E., Widodo, G. P. (2013). Analisis Pengendalian Obat Sitostatika Dengan Metode Eoq Dan Rop. Analisis Pengendalian Obat Sitostatika Dengan Metode Eoq Dan Rop. Jurnal Manajemen Dan Pelayanan Farmasi (Journal of Management and Pharmacy Practice), 3(3), 203-210. https://doi.org/10.22146/jmpf.194

Fan, L., Wilson, W. W., and Tolliver, D. (2009). Logistical rivalries and port competition for container flows to US markets: Impacts of changes in Canada's logistics system and expansion of the Panama Canal. Maritime Economics and Logistics, 11(4), 327-357. https://doi.org/10.1057/mel.2009.15

Gurumurthy, A., Nair, V. K., and Vinodh, S. (2020). Application of a hybrid selective inventory control technique in a hospital: a precursor for inventory reduction through lean thinking. TQM Journal, ahead-of-p(ahead-of-print).

https://doi.org/10.1108/TQM-06-20200123

Hales, D. N., Chang, Y. T., Lam, J. S. L., Desplebin, O., Dholakia, N., and AlWugayan, A. (2017). An empirical test of the balanced theory of port competitiveness. International Journal of Logistics Management, 28(2), 363-378. https://doi.org/10.1108/IJLM-06-20150101

Hartih, N. A., Satibi, and Widodo, G. P. (2013). Penerapan Metode Economic Order Quantity Dan Reorder Point Dalam Meningkatkan Efisiensi Persediaan Obat Reguler Di Instalasi Farmasi Rumah Sakit. Jurnal Manajemen Dan Pelayanan Farmasi (Journal of Management and Pharmacy Practice), 3, 249-254.

Heizer, J., Render, B., and Munson, C. (2017). Principles of Operations Management; Sustainability and Suply Chain Management. In Principles of Operations Management.

Kementerian Kesehatan RI Farmalkes. (2020). Pedoman Penyusunan Rancangan Kebutuhan Obat dan Pengendalian Persediaan Obat di Rumah Sakit. Retrieved from https://farmalkes.kemkes.go.id/2020/01/ pedoman-penyusunan-rancangankebutuhan-obat-dan-pengendalianpersediaan-obat-di-rumah-sakit/

Lai, S., Lin, Y., Luo, J., Li, X., and Li, S. (2021). Informationization Design of Field Standardized Operation Management System for Medium and Low Voltage Distribution Network. Journal of Physics: Conference Series, 1915(4), 42093. https://doi.org/10.1088/17426596/1915/4/042093

Minken, H., and Johansen, B. G. (2019). A logistics cost function with explicit transport costs. Economics of Transportation, 19(1), 100-116. https://doi.org/10.1016/j.ecotra.2019.04. 001

Octaviany, M. (2018). Analisis Pengendalian Persediaan Obat Antibiotik Di Rs Meilia Pada Tahun 2014 Dengan Menggunakan Metode Analisis Abc Indeks Kritis. Jurnal Administrasi Rumah Sakit Indonesia, 4, 147-160.

Rochmah, T. N. (2019). Menilik Manajemen Persediaan Obat di Rumah Sakit. UNAIR News. Retrieved from http://news.unair.ac.id/2019/09/24/menili k-manajemen-persediaan-obat-dirumah-sakit/

Satibi. (2014). Manajemen Obat di Rumah Sakit. Yogyakarta: UGM Press.

Tongzon, J., Chang, Y. T., and Lee, S. Y. (2009). How supply chain oriented is the port sector? International Journal of Production Economics, 122(1), 21-34. https://doi.org/10.1016/j.jpe.2009.03.01 7

Ugboma, C., Ugboma, O., and Ogwude, I. C. (2006). An Analytic Hierarchy Process (AHP) Approach to Port Selection Decisions - Empirical Evidence from Nigerian Ports. Maritime Economics and Logistics, 8, 251-266. https://doi.org/10.1057/palgrave.mel.910 0160

World Health Organization. (2014). GOOD GOVERNANCE IN THE PHARMACEUTICAL SECTOR. Retrieved from https://www.who.int/medicines/areas/go vernance/ggm_tunis_meeting_report.pd f?ua $=1$ 